\title{
Effects of gamma irradiation on color removal from reactive red 24 aqueous solutions
}

- Ha Bui Manh

Department of Environmental Sciences, Sai Gon University

- Duy Nguyen Ngoc

- Hien Nguyen Quoc

Research and Development Center for Radiation Technology, Vietnam Atomic Energy Institute

(Received 15 February 2016, accepted 11 April 2016)

ABSTRACT

Decolorization from synthetic wastewater containing Reactive Red 24 (RR24) using gamma Cobalt-60 ray was investigated. The influence of the irradiation dose, initial $\mathrm{pH}$, initial dye and hydrogen peroxide $\left(\mathrm{H}_{2} \mathrm{O}_{2}\right)$ concentration were evaluated. The pH effect has proved that lower decolorization efficiency was observed in alkaline medium as compared to the neutral and acid medium. While color removal efficiency increased with increasing absorbed dose. A synergistic effect of gamma radiation with $\mathrm{H}_{2} \mathrm{O}_{2}$ was applied and the results showed that $\mathrm{H}_{2} \mathrm{O}_{2}$ accelerated decolorization process, however when the dosage of $\mathrm{H}_{2} \mathrm{O}_{2}$ exceeded the optimal concentration, the color removal efficiency attained saturation and even reduced. The color removal efficiencies achieved over $99 \%$ at the dose of $4 \mathrm{kGy}$, initial $\mathrm{pH} 7$, initial dye concentrationof $100 \mathrm{mg} / \mathrm{L}$ and $\mathrm{H}_{2} \mathrm{O}_{2}$ concentration of $3 \mathrm{mM}$. These results highlighted the potential of radiation technology for dye removal from textile wastewater.

Keywords: Decolorization, gamma irradiation, reactive red 24 , textile wastewater.

\section{INTRODUCTION}

Reactive dye-containing wastewater is one of the most difficult wastewater to treat, because most of reactive dye has complex chemical structures with high water-solubility. Moreover, the dye structures are commonly highly resistant to biodegradation process.

One of the greatest concerns in wastewater treatment of a textile effluent is the color removal. Various types of techniques have been used to eliminate color including adsorption, chemical coagulation, photodegradation, membrane, ozonation, sonolysis, etc. [1-3]. Nonetheless, most of these techniques are limited by technology, cost or difficulties in operation. Hence, they could not be employed to treat real dyeing wastewater.

Recently, ionizing radiation methods such as gamma radiation and electron beam, a kind of oxidation method which could induce an amounts of oxidizing species $\left(\mathrm{OH}^{\circ}, \mathrm{H}_{2} \mathrm{O}_{2}, \mathrm{HO}_{2}{ }^{\circ} \ldots\right)$ and

\section{Trang 38}


reducing species $\left(\mathrm{e}_{\mathrm{aq}}^{-}\right.$and $\left.\mathrm{H}^{*}\right)$ through water radiolysis [4], received great attention for the effective treatment of toxic pollutants.

The gamma radiation has been successfully to treat slaughterhouse wastewater [5], coking wastewater [6], pesticide production wastewater [7], pharmaceutical wastewater [8] , and also drinking water [9]. However, the ionizing radiation process normally required high irradiation dose (or irradiation time) to degrade the complex organic compounds [10-12]. In this way, there is a need for an effective and nonhazarsous method could combine with the ionizing radiation process. Hydrogen peroxide $\left(\mathrm{H}_{2} \mathrm{O}_{2}\right)$ could be the key to the problem. Some reports $[8,13,14]$ indicate that adding small amounts of hydrogen peroxide could improve the irradiation capacity through increasing the formation of $\mathrm{OH}$ radicals as follows:

$$
\begin{aligned}
\mathrm{e}_{\mathrm{aq}}^{-}+\mathrm{H}_{2} \mathrm{O}_{2} & \rightarrow{ }^{\bullet} \mathrm{OH}+\mathrm{OH}^{-} \\
\mathrm{H}^{\bullet}+\mathrm{H}_{2} \mathrm{O}_{2} & \rightarrow{ }^{\bullet} \mathrm{OH}+\mathrm{H}_{2} \mathrm{O}
\end{aligned}
$$

Yulin et al. [15] had also demonstrated that the gamma irradiation $/ \mathrm{H}_{2} \mathrm{O}_{2}$ process was more cost-effective than sole $\mathrm{H}_{2} \mathrm{O}_{2}$ or irradiation. Nonetheless, as the concentrations of $\mathrm{H}_{2} \mathrm{O}_{2}$ are exceeded the optimal value, the degradation rates are reduced due to the scavenging of $\mathrm{OH}$ radical formation as follows [14]:

$$
\begin{array}{r}
\mathrm{H}_{2} \mathrm{O}_{2}+{ }^{\circ} \mathrm{OH} \rightarrow \mathrm{HO}_{2}{ }^{\circ}+\mathrm{H}_{2} \mathrm{O} \\
\mathrm{HO}_{2}{ }^{\cdot}+{ }^{\cdot} \mathrm{OH} \rightarrow \mathrm{H}_{2} \mathrm{O}+\mathrm{O}_{2}
\end{array}
$$

The inconsistency of the reports implies that synergic effects of gamma irradiation and $\mathrm{H}_{2} \mathrm{O}_{2}$ in wastewater treatment technology should be continuingly explored.

To the best of our knowledge, there has been no research on the treatment of Suncion Red P2B (RR24) aqueous solution by gamma irradiation method reported so far. The objective of this study is to investigate the decolorization of RR24 aqueous solution using gamma Co-60 radiation in the presence and absence of $\mathrm{H}_{2} \mathrm{O}_{2}$ with dose up to $12 \mathrm{kGy}$.

\section{MATERIALS AND METHODS}

Reagents and apparatus

All chemicals were reagent grade, SigmaAldrich and hydrogen peroxide $\left(\mathrm{H}_{2} \mathrm{O}_{2}\right)$ obtained from Merck, Germany.

The commercial Suncion Red P-2B (RR24) was supplied by Oh-Young (a Korean company) with a molecular structure and characteristics as summarized in Table 1.

Table 1. Characteristics of RR24

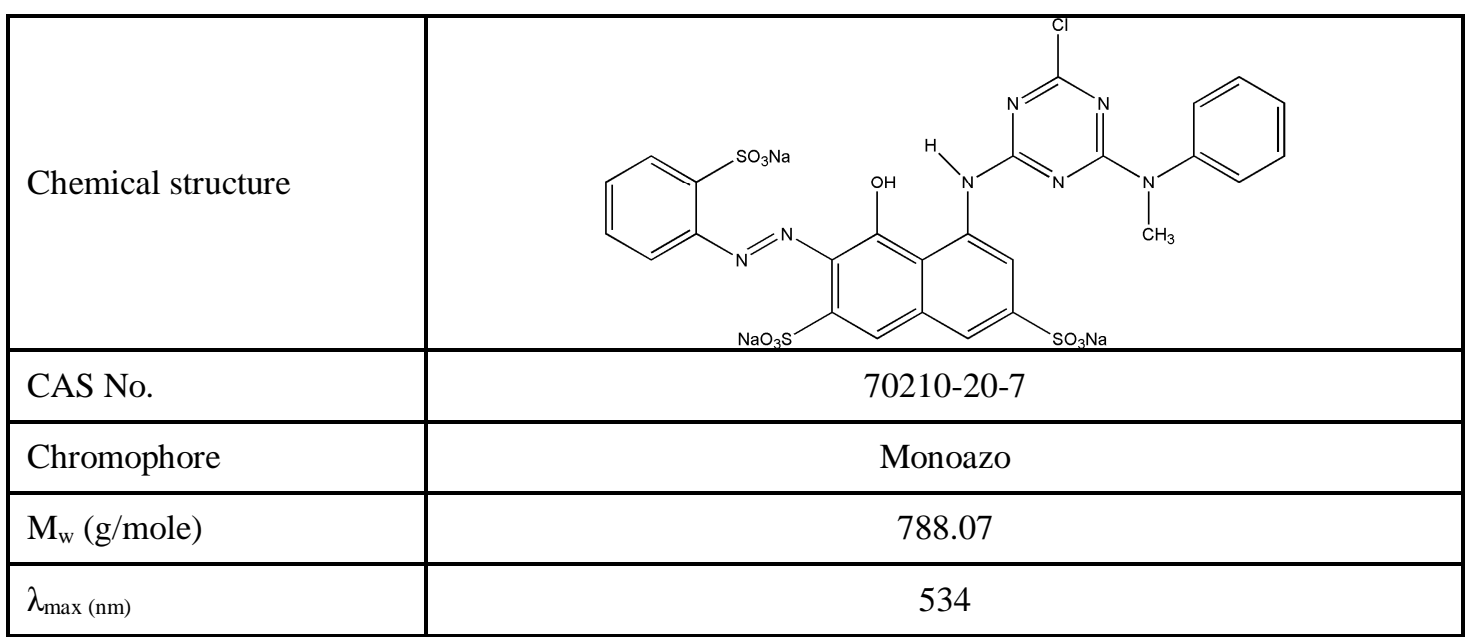


The dye stock solution (1000 mg/L) was achieved by completely dissolving 1 gram of dye powder into 1 liter of distilled hot water at $\mathrm{pH} 11$ for an hour to get the dye stock in the "hydrolyzed" form, and the solution was diluted to appropriate concentrations (30-200 $\mathrm{mg} / \mathrm{L})$ before being used.

\section{Procedures and analysis methods}

Firstly, $1000 \mathrm{~mL}$ beaker containing $500 \mathrm{~mL}$ of the dye solution with specific concentration $(30,50,80,120,150,180$, and $200 \mathrm{mg} / \mathrm{L})$ were adjusted to the different $\mathrm{pH}$ values $(1,2,3,5,7$, 9 , and 11$)$ by $\mathrm{NaOH}$ or $\mathrm{HCl}(0.05 \mathrm{~N})$ solutions. Secondly, an amount of $\mathrm{H}_{2} \mathrm{O}_{2}$ was added to reach the solution desired $\mathrm{H}_{2} \mathrm{O}_{2}$ concentration $(0,1,2$, 3 , 4, and $5 \mathrm{mM}$ ). Then $400 \mathrm{~mL}$ of the solution were poured into $500 \mathrm{~mL}$ glass bottle (Schott, Germany), packed with a dichromate dosimeter and irradiated with different doses of gamma rays $(1-12 \mathrm{kGy})$ at room temperature $\left(25 \pm 1^{\circ} \mathrm{C}\right)$ on a gamma Co-60 irradiator (Gamma chamber GC-5000, BRIT, India) at Nuclear Research Institute, Dalat, Viet Nam.

The irradiated water samples were then settled for two hours; then filtered and determined the absorbance at maximum absorption wavelength $\left(\lambda_{\max }\right) 541 \mathrm{~nm}$ using spectrophotometer UV-VIS GENESYS 10 (Thermo Fisher, Germany). The degree of decolorization was calculated from the decrement of absorbance at this maxium wavelength. $\mathrm{pH}$ was measured with a SevenEasy $\mathrm{pH}$-meter
(Mettler-Toledo, Switzerland). While the absorbed dose of the gamma rays were validated using the dichromate dosimetry method [16]. All analyses were conducted in triplicate and results presented here are the mean values \pm standard deviations.

\section{RESULTS AND DISCUSSION}

\section{Influence of rrradiation dose}

In the gamma irradiation process, irradiation dose determines the hydroxyl radical formation rate hence affects the decolorization efficiency [4]. In order to examine the effect of irradiation dose on decolorization, the experiment was carried out using various irradiation doses from 0 to $12 \mathrm{kGy}$ at $\mathrm{pH} 9,100 \mathrm{mg} / \mathrm{L}$ of dye concentration with no adding $\mathrm{H}_{2} \mathrm{O}_{2}$.

As expected, the increasing irradiation dose had a dramatic impact on the color removal, there was approximately a linear relationship between irradiation dose and color removal of dye (Figure 1). Also, high rate of color removal efficiencies were obtained when irradiation dosage increment from 0 to $4 \mathrm{kGy}$. It may due to the hydroxyl radical increased in dye solution with the increase of irradiation dose [4] and finally attains saturation when equilibrium (between the dye and radical) was reached [8]. These results are similar to the irradiation dose recommended by Guo and Shen [6]. So, the suitable irradiation dose of $4 \mathrm{kGy}$ was selected for the next experiment.

\section{Trang 40}




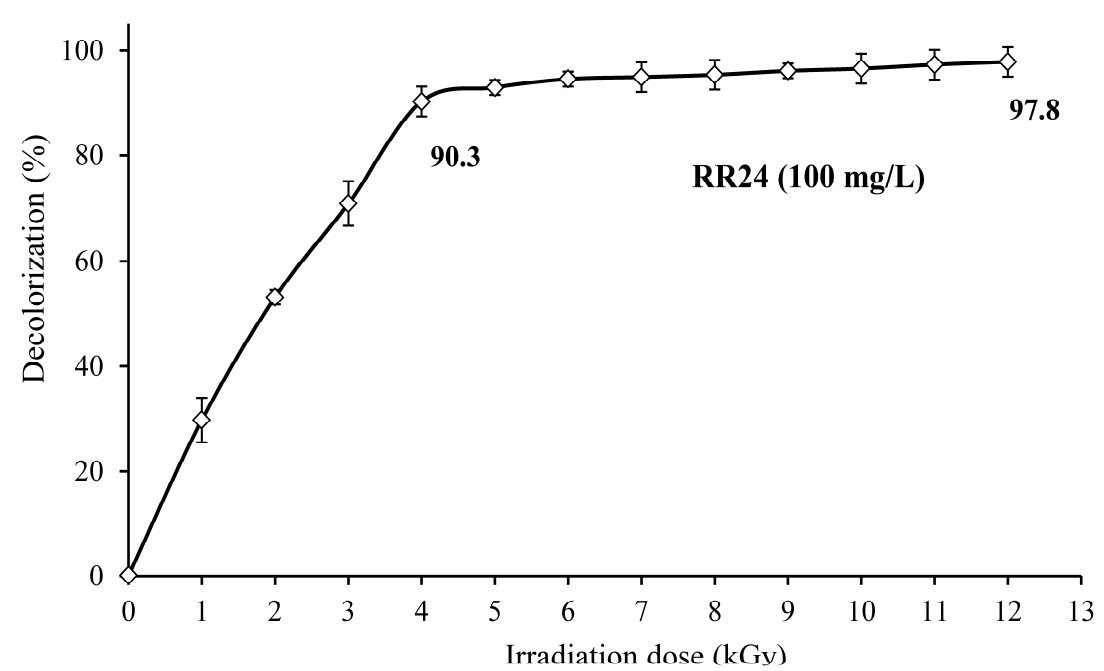

Figure 1. Effect of irradiation dose on removal efficiency at $\mathrm{pH} 9$ without $\mathrm{H}_{2} \mathrm{O}_{2}$

Influence of initial dye concentration

The effect of initial dye concentration (IDC) on the color removal of the irradiation experiment was investigated. IDC was from 30 to $200 \mathrm{mg} / \mathrm{L}$ and irradiated with the fixed irradiation dose $4 \mathrm{kGy}$ at $\mathrm{pH} 9$ without adding $\mathrm{H}_{2} \mathrm{O}_{2}$. The results of color removal efficiency in Figure 2 indicated that the IDC upped to $100 \mathrm{mg} / \mathrm{L}$, the irradiation capacity was not exhausted and the degree of color removal was slightly reduced from $98.6 \pm 1.0 \%(30 \mathrm{mg} / \mathrm{L})$ to $90.8 \pm 1.7 \%$ $(100 \mathrm{mg} / \mathrm{L})$. However, beyond $100 \mathrm{mg} / \mathrm{L}$, the degree of the color removal was sharply decreased. The reason may be due to the IDC is rather high.

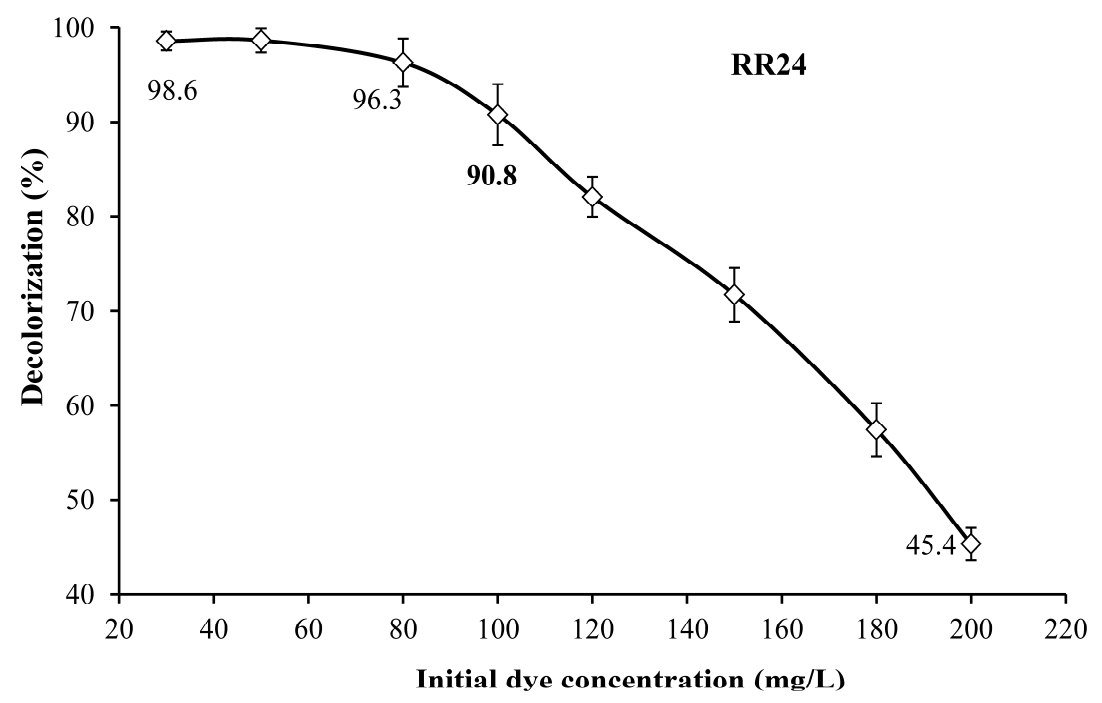

Figure 2. Effects of IDC on removal efficiency at $\mathrm{pH} 9$ and dose $4 \mathrm{kGy}$ without $\mathrm{H}_{2} \mathrm{O}_{2}$

\section{Effect of $p H$}

It has been established that $\mathrm{pH}$ plays an important role in impacting on the performance of dye irradiation process because it could affect both the specialization of dye [17] and the formation of radicals which could react with pollutants [4]. A series of experiments were 
carried out by varying the $\mathrm{pH}$ from 1 to 11 by using $0.05 \mathrm{~N} \mathrm{NaOH}$ (or $\mathrm{HCl}$ ), with IDC of 100 $\mathrm{mg} / \mathrm{L}$ and irradiation dose of $4 \mathrm{kGy}$. The color removal of the dye solution was influenced by $\mathrm{pH}$ in Figure 3 showed that the decolorization efficiency decreased with the increasing of initial $\mathrm{pH}$ from $1(99.6 \pm 0.4 \%)$ to $11(89.4 \pm 0.6 \%)$.
This may be due to the dissociation ability of dyeing substances at organic phase is increased at low $\mathrm{pH}$ [17] and the dye could react efficiently with hydroxyl radical at lower $\mathrm{pH}$ value [4]. Similar trend was also reported in the research of Dessouki et al. [7] for eliminating of pesticides.

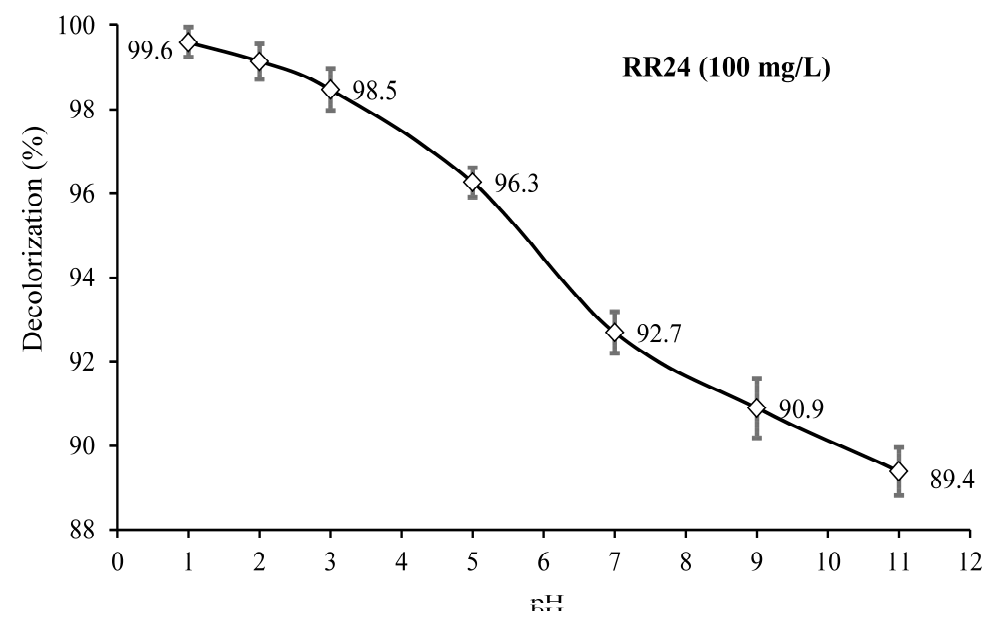

Figure 3. Effect of $\mathrm{pH}$ on color removal efficiency at $4 \mathrm{kGy}$ of irradiation dose without $\mathrm{H}_{2} \mathrm{O}_{2}$

Although the lower $\mathrm{pH}$ was, the higher color removal efficiency achieved, but in fact, it needs a great amount of neutralizing acids consumption to justify $\mathrm{pH}$ from 9 (normal value of waste water source after the reactive dyeing processes) down to $\mathrm{pH}$ of 1 or 2 . Furthermore, in the acidic environment, the corrosion likelihood of irradiation and related facility often occurs. Therefore, $\mathrm{pH} 7$ was typical for further investigation.

\section{Effect of hydrogen peroxide concentration}

Prerious studies [7, 8] reported that the presence of $\mathrm{H}_{2} \mathrm{O}_{2}$ in the solution could lead the formation of hydroxyl radical which contribute the treatment efficiency. In order to investigate the synergistic decolorization of gamma Co-60 and $\mathrm{H}_{2} \mathrm{O}_{2}$, a series of experiments were perfromed at different concentration of $\mathrm{H}_{2} \mathrm{O}_{2}$ from 0 to $5 \mathrm{mM}$. The results obtained were presented in Figure 4. 


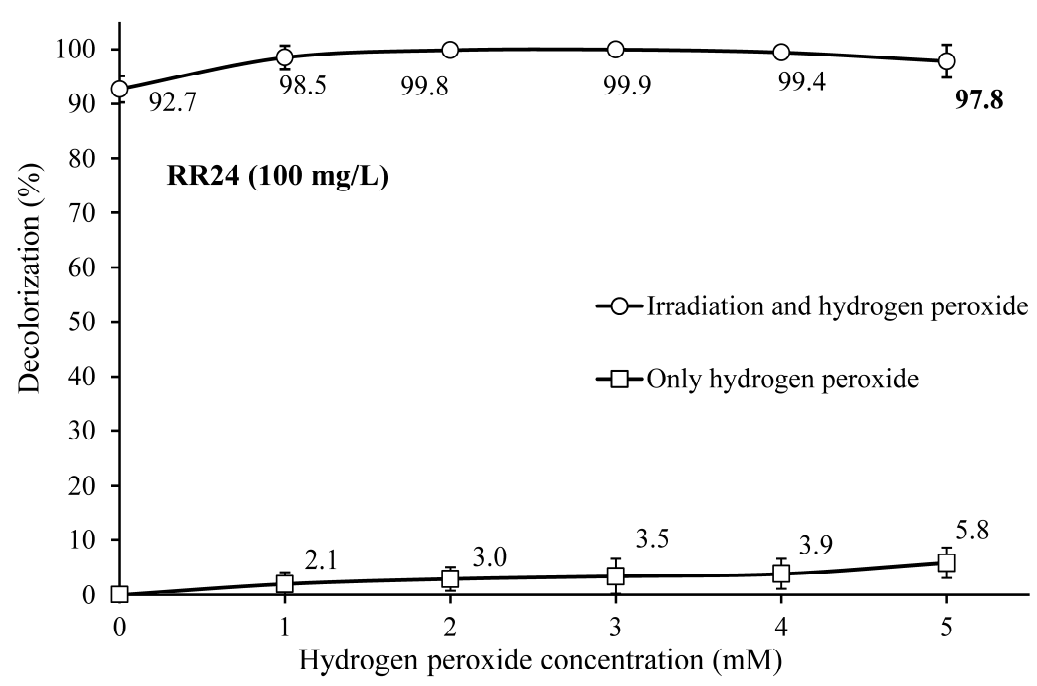

Figure 4. Effects of IDC on removal efficiency at $\mathrm{pH} 7$ and $4 \mathrm{kGy}$ of irradiation dose

Results in Figure 4 illustrated that color removal efficiency depended remarkably on $\mathrm{H}_{2} \mathrm{O}_{2}$ concentration. The decolorization percentage for the $\mathrm{H}_{2} \mathrm{O}_{2}$ alone increased only to $5.8 \pm 2.7 \%$ at the highest $\mathrm{H}_{2} \mathrm{O}_{2}$ concentration (5 $\mathrm{mM})$. Whereas, as combining irradiation with $\mathrm{H}_{2} \mathrm{O}_{2}$, color removal degree increased from 92.7 $\pm 2.4 \%$ (without $\left.\mathrm{H}_{2} \mathrm{O}_{2}\right)$ to $99.9 \pm 0.1 \%(3 \mathrm{mM}$ $\mathrm{H}_{2} \mathrm{O}_{2}$ ). The combined effect of $\mathrm{H}_{2} \mathrm{O}_{2}$ and radiation was much higher than the effect of either component, or even of the sum of the individual effect. These results mean that irradiation and $\mathrm{H}_{2} \mathrm{O}_{2}$ induced the decomposition of dye efficienly because of the abundant hydroxyl radical produced from irradiation of dye solution in the presence of $\mathrm{H}_{2} \mathrm{O}_{2}$ as described in equations 1 and 2 [4]. Nevertheless, when $\mathrm{H}_{2} \mathrm{O}_{2}$, concentration was in the range of $3-5 \mathrm{mM}$, the color removal degree dropped slightly from 99.9 $\pm 0.1 \%(3 \mathrm{mM})$ to $97.8 \pm 3.0 \%(5 \mathrm{mM})$. This phenomenon may be due to an excessive $\mathrm{H}_{2} \mathrm{O}_{2}$ promotes an inhibitory effect (hydroxyl radical scavenging) and the formation of another radical $\left(\mathrm{HO}_{2}{ }^{\circ}\right)$, having an oxidation potential considerably smaller than $\mathrm{HO}^{\circ}$ as described in equations 3 and 4 [4].

\section{CONCLUSIONS}

Gamma Co-60 irradiation proved to be an effective method for decolorization of reactive red 24 (RR24) dye solution. The color removal of the dye solution was almost $99.9 \pm 0.1 \%$ at the initial dye concentration of $100 \mathrm{mg} / \mathrm{L}$ and absorbed dose of $4 \mathrm{kGy}$. The synergistic effect of gamma Co-60 irradiation and $\mathrm{H}_{2} \mathrm{O}_{2}$ was found out at $\mathrm{H}_{2} \mathrm{O}_{2}$ concentration of $3 \mathrm{mM}$ as suitable one. Thus, radiation technology is considered as a new method for decolorization of textile wastewater. 


\section{Nghiên cứu loại màu dung dịch nhuộm hoạt tính Red 24 bằng bức xạ Gamma Co- 60}

- Bùi Mạnh Hà

Khoa Khoa học Môi trường, Trường đại học Sai Gòn

- Nguyễn Ngọc Duy

- Nguyễn Quốc Hiến

Trung tâm Nghiên cứu và Triển khai Công nghệ Bức xạ, Viện Năng lượng Nguyên tử Việt Nam

\section{TÓM TẮT}

Nghiên cứu giảm màu trong dung dịch nhuộm họat tính reactive red 24 bằng bức xa gamma Co-60 dược thục hiện. Anh huơơng của liều xa, pH, nồng độ màu và nồng độ $\mathrm{H}_{2} \mathrm{O}_{2}$ đuợc khảo sát. Kết quả cho thấy hiệu suất khử màu tăng khi tăng liều xạ, pH môi truờng acid hoăc trung tính có hiệu quả xủ lý cao hơn trong môi truờng kiềm. Hiệu ứng đồng vận của bức xa với

màu bằng chiếu xạ, tuy nhiên khi nồng độ $\mathrm{H}_{2} \mathrm{O}_{2}$ vuọt quá nồng độ tối uu (3 $\mathrm{mM}$ ) lại làm giảm hiệu quả khư màu. Hiệu quả khử màu bằng chiếu $x$ a đạt 99,9 $\pm 0,1 \%$ tại $p H 7$, nồng độ $\mathrm{H}_{2} \mathrm{O}_{2} 3$ mM, nồng độ màu nhuộm $100 \mathrm{mg} / \mathrm{l}$ và liều xạ 4 $k G y$. Kết quả nghiên cứu cho thấy phuơng pháp chiếu xa rất có hiệu quả trong việc giảm màu trong nuớc thải nhuộm hoạt tính. $\mathrm{H}_{2} \mathrm{O}_{2}$ cũng cho thấy $\mathrm{H}_{2} \mathrm{O}_{2}$ thúc đẩy quá trình khủ

Tù khóa: $\mathrm{H}_{2} \mathrm{O}_{2}$, bức xạ gamma Co-60, màu nhuộm red 24, nuớc thải nhuộm hoạt tính.

\section{REFERENCES}

[1]. Alinsafi A., Khemis M., Pons M. N., Leclerc J. P., Yaacoubi A., Benhammou A., Nejmeddine A., Electro-coagulation of reactive textile dyes and textile wastewater. Chem. Eng. Process. 44 (4), 461 (2005).

[2]. Kim T.-H., Park C., Kim S., Water recycling from desalination and purification process of reactive dye manufacturing industry by combined membrane filtration. J. Clean Prod. 13 (8), 779 (2005).

[3]. Lee J. W., Choi S. P., Thiruvenkatachari R., Shim W.-G., Moon H., Submerged microfiltration membrane coupled with alum coagulation/powdered activated carbon adsorption for complete decolorization of reactive dyes. Water Res. 40 (3), 435 (2006).

[4]. LaVerne J. A., OH radicals and oxidizing products in the gamma radiolysis of water. Radiat. Res. 153 (2), 196 (2000).

[5]. Melo R., Verde S. C., Branco J., Botelho M. L., Gamma radiation induced effects on slaughterhouse wastewater treatment. Radiat. Phys. Chem. 77 (1), 98 (2008).

[6]. Guo F., Shen H., Study of gamma irradiation-induced effects on organic pollutants and suspended solids in coking wastewater. Desalin. Water Treat. 52 (1012), 1850 (2013).

Trang 44 
[7]. Dessouki A. M., Aly H. F., Sokker H. H., The use of gamma radiation for removal of pesticides from waste water. Czech J. Phys. 49 (1), 521 (1999).

[8]. Sánchez-Polo M., López-Peñalver J., Prados-Joya G., Ferro-García M. A., RiveraUtrilla J., Gamma irradiation of pharmaceutical compounds, nitroimidazoles, as a new alternative for water treatment. Water Res. 43 (16), 4028 (2009).

[9]. Gehringer P., Proksch E., Eschweiler H., Szinovatz W., Removal of chlorinated ethylenes from drinking water by radiation treatments. Int. J. Radiat. Appl. Instrum. C Radiat. Phys. Chem. 35 (1), 456 (1990).

[10].Lee D. W., Choi W. S., Byun M. W., Park H. J., Yu Y.-M., Lee C. M., Effect of $\gamma$ Irradiation on Degradation of Alginate. $J$. Agric. Food Chem. 51 (16), 4819 (2003).

[11].Soebianto Y. S., Kusuhata I., Katsumura Y., Ishigure K., Kubo J., Kudoh H., Seguchi T., Degradation of polypropylene under gamma irradiation: protection effect of additives. Polym. Degrad. Stab. 50 (2), 203 (1995).

[12].Shawrang P., Nikkhah A., Zare-Shahneh A., Sadeghi A. A., Raisali G., MoradiShahrebabak M., Effects of gamma irradiation on protein degradation of soybean meal in the rumen. Anim. Feed Sci. Technol. 134 (1-2), 140 (2007).

[13]. Yu S., Hu J., Wang J., Gamma radiationinduced degradation of p-nitrophenol (PNP) in the presence of hydrogen peroxide $(\mathrm{H} 2 \mathrm{O}$ 2) in aqueous solution. J. Hazard. Mater. 177 (1), 1061 (2010).

[14].Getoff N., Factors influencing the efficiency of radiation-induced degradation of water pollutants. Radiat. Phys. Chem. 65 (4), 437 (2002).

[15].Yulin X., Weijiang Z., Hao Z., Synergetic decolorization and deodorization of sludge protein foaming solution by $60 \mathrm{Co} \gamma$-ray irradiation/H2O2 oxidation. Process Saf. Environ. 88 (4), 285 (2010).

[16].ISO/ASTM, 2003. Standard Practice for Use of a Dichromate Dosimetry System. 69: American Society for Testing and Materials International.

[17].Perng Y. S., Bui H. M., The feasibility of cassia fistula gum with polyaluminium chloride for decolorization of reactive dyeing wastewater. J. Serb. Chem. Soc. 80 (1), 115 (2015). 